International Journal of Foundations of Computer Science Vol. 4 No. 1 (1993) 99 (C) World Scientific Publishing Company

\title{
ERRATUM
}

\section{ITERATION ALGEBRAS}

[Int. J. Found. Comput. Sci. Vol. 3 No. 3 (1992) 245-302]

\author{
STEPHEN L. BLOOM \\ Stevens Institute of Technology \\ Department of Computer Science, Hoboken, NJ 07030, USA \\ ZOLTÁN ÉSIK \\ A. József University \\ Bolyai Institute, Szeged, Hungary
}

The dates of receipt of the paper should be:

Received 13 September 1990

Revised 23 September 1991

The paper was communicated by E. Engeler. 